\title{
Lacrimal Artery
}

National Cancer Institute

\section{Source}

National Cancer Institute. Lacrimal Artery. NCI Thesaurus. Code C52948.

An artery originating from the ophthalmic artery with many branches that supply

numerous areas including the lacrimal gland, eyelids and forehead. 